\title{
Impact of bio and mineral fertilizers on growth, yield and its components of roselle plants (Hibiscus sabdariffa, L.) grown under different types of soil
}

\begin{abstract}
A field experiment was carried out during the two successive seasons 2007 and 2008 to study the effect of bio fertilizers namely, Azotobacterine (Azotobacter chroococcum) and phosphorein (Bacillus polymyxa), mineral N, P and K fertilizers at the rates of 25, 50 and $100 \%$ for each fertilizer (from the doses recommended by Ministry of Agriculture) on growth (plant height, number of branches and herb fresh and dry weights/plant), yield (dry weight of sepales/plant and feddan and weight of seeds/plant and feddan) of roselle plants (Hibiscus sabdariffa, L.) under different soils (clay soil at Dar El-Ramad farm, sandy loam and saline loamy sand soil at Demo farm, Faculty of Agriculture) at El-Fayoum governorate conditions. The data obtained showed that, bio and mineral (NPK) fertilizers increased the above characters of roselle plants under different soils of experiment. The maximum increase of these characters was obtained by the treatment clay soil $\times 100 \%$ NPK+bio fertilizers, followed by clay soil $\times 50 \%$ NPK+bio fertilizers as compared to saline loamy sand soil $\times$ non fertilizer treatment, although, the differences between these treatments and mineral fertilizer at the rate of $100 \%$ NPK alone were insignificantly. Therefore, it is economically and environmentally recommended to inoculate roselle seeds with mixture of Azotobacter+Bacillus and fertilize these inoculated plants with $50 \%$ improve the vegetative growth and augment the yield components of roselle plants under clay soil were obtained the best results of this work study.
\end{abstract}

Keywords: roselle, hibiscus sabdariffa 1, nitrogen, phosphorus, bio fertilization, soi type, salinity, growth, yield
Volume 3 Issue 5 - 2019

\author{
Samir SI Ghabour,' Saad A Mohamed, \\ Sawsan A Saif El-Yazal,' Hasan M.H. Moawad' \\ 'Soil and water, Department, Faculty of Agriculture, Fayoum \\ University, Egypt \\ ${ }^{2}$ Botany Department, Faculty of Agriculture, Fayoum University, \\ Egypt
}

Correspondence: Mohamed A Seif El-Yazal, Botany Department, Faculty of Agriculture, Fayoum University, Fayoum 63514, Egypt, Email mas04@fayoum.edu.eg

Received:September 09, 2019 | Published: October 15, 2019

\section{Introduction}

Roselle (Hibiscus sabdariffa, L.) belongs to the family Malvaceae. It is now widely cultivated throughout the tropics and sub tropics e.g. Sudan, China, Thailand, Egypt, Mexico, and the west India. Roselle plant is branched, glabrous, annual sub shrub, 0.5-3 m. high, with strong taproot. Roselle is cultivated mainly in Upper Egypt and grows well under different environmental conditions such as high temperature. ${ }^{1}$ Plants require specific amount of certain nutrients in specific form at appropriate time, for their growth and development. ${ }^{2}$ To determine the rates of $\mathrm{N}$ fertilizer application, it is necessary to take into account the inorganic $\mathrm{N}$ of the soil and the organic $\mathrm{N}$ mineralized during crop growth. ${ }^{3}$ Environmental problems caused by irregular application of chemical fertilizers, inappropriate energy production methods and excessive consumption costs have all had harmful effects on biological cycles and destroyed farming stability systems; these factors altogether encourage the application of biofertilizers. ${ }^{4}$ Nowadays attention to biological fertilizer has been increased due to countries development, prices of chemical fertilizers and attention to sustainable agricultural systems. ${ }^{5}$ Nitrogen is required in large quantities for plants growth, since it is the basic constituent of proteins and nucleic acids. Nitrogen is provided in the form of synthetic chemical fertilizer. Excessive use of such chemical fertilizers for increasing crop yield cased health hazard and microbial population problems in soil besides beings quite expensive and making the cost of production high. ${ }^{6}$ Bio-as a microbial-based fertilizer composed of different microorganism that has the ability to fix atmospherec $\mathrm{N}$ making it available for plant growth which can drastically reduce Nfertilizer input and enhance the yield of wheat. These bacteria can convert the gaseous nitrogen from the air to ammonia at an equivalent rate of $40 \mathrm{~kg}$ of $\mathrm{N}$ per hectare or higher. It complements the use of chemical fertilizer by $30-50 \%$, an apparent big savings for the farmers. Other results show that Bio-N inoculation, in the presence of $50 \%$ the recommended mineral fertilizer, could parallel the yield of fully fertilized corn. ${ }^{7}$ Several researchers reported that inoculation of some plants with bio fertilizers (singly or in different combinations with mineral fertilizers) improved plant growth, yield and chemical composition..$^{8-11}$ Moreover, several researchers justified the idea that nutrients like $\mathrm{N}$ may be taken up through roots and leaves and may spread within the plant. ${ }^{11,12-15}$ Therefore, the use of phosphate solubilising microbes along with the applied phosphate can provide a solution to the menace of accumulation of phosphates in the fields and water bodies. Bacillus sp. are well-known rhizobacteria which facilitate the plant growth either by solubilization of minerals like phosphorus or production of metabolites such as siderophores and phytohormones, and are excellent colonizers of the roots. ${ }^{16}$ Several researchers justified the idea that nutrients like phosphorus may be taken up through roots and leaves and may spread within the plant. ${ }^{17-21}$ Many investigators agreed that application of phosphate dissolving bacteria; Bacillus megaterium increased growth characters. ${ }^{22-26}$

The aim of this work was to study the integrated effect of N\&P bio fertilizers plus N\&P as soil application at different rates on growth and yield of roselle plants.

\section{Material and methods}

A field experiment were conducted during the two successive seasons of 2007and 2008 to study the effect of bio, nitrogen and phosphorus fertilizers on growth, yields and its components of roselle plants (Hibiscus sabdariffa, L.) under different types of soil 
at El-Fayoum governorate conditions. Three types of soil in two experimental stations of the Faculty of Agriculture, namely clay soil at the Dar El-Ramad farm, a saline loamy sand and sandy loam soil at Demo farm. Some chemical and physical characteristics of the experimental stations soils are presented in Table $1 \&$ Table 2

Biofertilizers namely Azotobacterine (Azotobacter chroococcum) as nitrogen fixing bacteria and phosphorein (Bacillus polymyxa) as a phosphate dissolving bacteria were obtained from Agricultural Research Center, Ministry of Agriculture, Egypt.The seed of roselle cv. Sabahia 17 were obtained from the Research Center of Medicinal and Aromatic Plants, Ministry of Agriculture, Egypt. Seeds were immersed in Arabic gum solution (16\%) as a sticking agent, then, the seeds were mixed with the powder of mixed biofertilizers; inoculated seeds were allowed to dry before sowing, according to Allen. ${ }^{27}$ Application of N, P and K fertilizers were 100, 50 and $25 \%$ for each fertilizer from that recommended doses by the Ministry of Agriculture, $500 \mathrm{~kg}$ ammonium sulfate $(20.6 \% \mathrm{~N}), 150 \mathrm{~kg}$ calcium superphosphate $\left(15 \% \mathrm{P}_{2} \mathrm{O}_{5}\right)$ and $50 \mathrm{~kg}$ potassium sulfate/fed $(48 \%$ $\mathrm{K}_{2} \mathrm{O}$ ). Nitrogen fertilizer was applied in two equal doses, the first dose during sowing and before the first irrigation, and the second dose after one month from sowing. Phosphorus and potassium fertilizers were applied during soil preparation (Table 3).

1- Non fertilizer 2- Biofertilizers 3- $100 \%$ NPK 4(Biofertilizers $+100 \% \quad$ NPK) $\quad 5-\quad$ (Biofertilizers $+50 \%$ NPK) $6-$ (Biofertilizers $+25 \%$ NPK)

The experimental field was plowed, rolled and divided into 54 plots, each one of $10.5 \mathrm{~m}^{2}$ area (1/400 fed) and contains 5 rows (3 $\mathrm{m}$ width and $3.5 \mathrm{~m}$ in length). The seeds inoculated were sown on $1^{\text {st }}$ and $2^{\text {nd }}$ May, in the two experimental seasons. Four seeds were sown per hill $(50 \mathrm{~cm}$ apart) on one side of the ridge. After one month from sowing the seedlings were thinned to one plant per hill. In this regard, each experimental unit (plot) contains 30 plants ( 6 plants/row) and $12000 \mathrm{plants} / \mathrm{fed}$. All other agricultural practices were followed as recommended in roselle management.

\section{Plant samples}

Samples of roselle plants ( 9 plants) were randomly chosen from each treatment ( 3 plants for each replicate) in the early morning after 140 days from sowing immediately transferred to the laboratory to study the following morphological characteristics and plant analysis.

i. Average plant height $(\mathrm{cm})$ was measured from the cotyldonary node to plant top of the main stem.

ii. Average number of branches/plant: was estimated by taking the average number of branches of nine plants.

iii. Average fresh weight (g): The samples were stemated by taking the average weight of nine plants.

iv. Average dry weight of herb g/plant: The samples were dried in an electric oven at $70^{\circ} \mathrm{C} \pm 2$ until constant weight was reached almost after 48 hours.

\section{Yield and its components}

At the age of 180 days from sowing, roselle plants were harvested (9 plants) from each treatment which randomly chosen to study the following parameters.

i. Dry weight of sepals g/plant: The dry weight of sepals plant (calyx and epicalyx) was recorded after drying in sunny place. ii. Dry sepals yield ( $\mathrm{kg} /$ feddan): The capsules were air-dried in suny place .The dry yield of sepals was calculated $(\mathrm{kg} / \mathrm{fed})$.

iii. Weight of seeds/plant (g): The capsules were collected and dried on paper sheet in suny open place. After drying, the seeds were separated and its dry weight was recorded.

iv. Weight of seeds ( $\mathrm{kg} /$ feddan): The weight of seeds/feddan was calculated from the weight of seeds/plot.

\section{Statistical analysis}

A split-split plot design was used. Also, all the collected data were reduced to proper format and units and were statistically analyzed using the procedures outlined by Snedecor and Cochran. ${ }^{28}$

\section{Results}

\section{A- Growth characters}

Data presented in Table 4 clearly indicate that the clay soil gave the highest growth parameters of roselle plant, (i.e. plant height, number of branches, herb fresh weight $\mathrm{Kg} /$ plant and herb dry weight $\mathrm{g} /$ plant) compared to sandy loam and saline loamy sand soil. The application of mineral fertilization $(100 \%$ NPK) on roselle growth parameters was significantly increased compared to the non-fertilizer in the first and second seasons. Data also show that bio fertilization treatment significantly increased roselle growth parameters in the first and second seasons, in comparison to non-fertilizer treatment respectively. Seeds inoculation with bio-N\&P fertilizer in combination with 25 , 50 and $100 \%$ from recommended N\&P dose as soil application improved the studied growth parameters of roselle plant, as compared to non-fertilizer treatment. Such trend was true during the two studied seasons. The interaction between mineral fertilizers (NPK) and bio fertilizers significantly affected the roselle growth parameters in the two experimental seasons. All growth parameters for plants received $100 \%$ NPK and inoculated with different bacteria strains were increased than those which did not received neither mineral NPK nor bio fertilization treatments. The most effective interaction treatments were $100 \%$ NPK+bio fertilizers followed by $50 \%$ NPK+bio fertilizers than $25 \% \mathrm{NPK}+$ bio fertilizers. The interaction of growth parameters between soil type and fertilizer treatments was increased at the treatment (clay soil $\times \mathrm{Bio}+100 \% \mathrm{NPK}$ ) in the first and second seasons, respectively above the lowest values at the treatment (saline loamy sand soil $\times$ non fertilizer).

\section{B- yield and its components}

Data presented in Table 5 showed that clay soil gave the heaviest yields and its components (Sepals dry weight g/plant, Sepals dry weight $\mathrm{kg} / \mathrm{fed}$, Weight of seeds $\mathrm{g} / \mathrm{plant}$ and Weight of seeds $\mathrm{kg} / \mathrm{fed}$ ) as compared to sandy loam and saline loamy sand soil in the first season and second season, respectively. A significant increment has been recorded on yields and its components by $100 \%$ mineral NPK treatment compared to unfertilized plants as listed in Table 5. In regard to bio fertilization, data also show that application of bio fertilization (with two bacteria species) led to significant increase in yields and its components in comparison with non-fertilizer in the experiments of two seasons. The combination between NPK and bio fertilizers significantly affected yields and its components in the experiments of the two seasons. The most effective interaction treatments were $100 \%$ NPK + bio fertilization followed by $50 \%$ NPK+bio fertilization than $25 \%$ NPK+bio fertilization. It was found a slight difference between $100 \%$ NPK and Bio $+50 \%$ NPK treatment. Data tabulated in Table 5 
show that the interaction between soil type and fertilizer treatments greatly increased yields and its components at the treatment (clay soil $\times \mathrm{Bio}+100 \% \mathrm{NPK}$ ) above the lowest values, at the treatment (saline loamy sand soil $\times$ non fertilizer) in the first and second seasons, respectively.

Table I Some physical and chemical properties of the used experimental soils (Dar El-Ramad and Demo farms) through season 2007

\begin{tabular}{llll}
\hline Soil properties & \multicolumn{2}{l}{ Season 2007 } & Dar E \\
\cline { 2 - 4 } & Demo & & \\
Physical properties & 28.69 & 30.20 & 5.14 \\
Coarse sand \% & 37.19 & 42.33 & 21.55 \\
Fine sand \% & 22.16 & 15.72 & 24.43 \\
Silt \% & 11.96 & 11.75 & 48.88 \\
Clay \% & Sandy loam & Loamy sand & Clay \\
Texture class & & &
\end{tabular}

\section{Chmical properties}

Organic matter \%

0.48

8.61

$\mathrm{CaCO}_{3} \%$

$\mathrm{pH}$ (soil paste)

ECe (paste extract), ds/m

Soluble anions, meq/L*

$\mathrm{CO}_{3}^{--}$

$\mathrm{HCO}_{3}^{-}$

$\mathrm{Cl}^{-}$

$\mathrm{SO}_{4}^{--}$

Soluble cations, $\mathrm{meq} / \mathrm{L}^{*}$

$\mathrm{Ca}^{++}$

$\mathrm{Mg}^{++}$

$\mathrm{Na}^{+}$

$\mathrm{K}^{+}$
30.75

6.15

6.89

17.41

6.80

15.03

26.15

2.13

0.61

0.79

0.72
Available nutrients, $\mathrm{ppm}^{* *}$

N

$P$

K

$\begin{array}{lll}3.54 & 4.44 & 21.02 \\ 6.87 & 6.42 & 12.27 \\ 54 & 36 & 83\end{array}$

* In saturation paste extract

**On dry weight basis 
Table 2 Some physical and chemical properties of the used experimental soils (Dar El-Ramad and Demo farms) through season 2008.

\begin{tabular}{lll}
\hline \multirow{3}{*}{ Soil properties } & Season 2008 & \\
\cline { 2 - 3 } & Demo & Dar El-Ramad \\
\hline
\end{tabular}

\section{Physical properties}

$\begin{array}{lccc}\text { Coarse sand \% } & 22.73 & 31.05 & 6.37 \\ \text { Fine sand \% } & 31.66 & 40.38 & 19.40 \\ \text { Silt \% } & 31.84 & 16.04 & 27.48 \\ \text { Clay \% } & 13.77 & 12.53 & 46.75 \\ \text { Texture class } & \text { Sandy loam } & \text { Loamy sand } & \text { Clay }\end{array}$

\section{Chmical properties}

$\begin{array}{lccc}\text { Organic matter \% } & 0.38 & 0.40 & 1.43 \\ \mathrm{CaCO}_{3} \% & 7.83 & 7.69 & 5.12 \\ \mathrm{PH} \text { (soil paste) } & 7.75 & 7.81 & 7.55 \\ \mathrm{ECe} \text { (paste extract), ds/m } & 3.64 & 7.26 & 2.10\end{array}$

Soluble anions, $\mathrm{meq} / \mathrm{L}^{*}$

$\mathrm{CO}_{3}^{--}$

$\mathrm{HCO}_{3}$

4.83

4.96

3.83

$\mathrm{Cl}^{-}$

15.42

35.43

10.29

$\mathrm{SO}_{4}^{--}$

16.15

32.21

6.88

Soluble cations, meq/L*

$\begin{array}{cccc}\mathrm{Ca}^{++} & 10.25 & 30.24 & 7.43 \\ \mathrm{Mg}^{++} & 7.32 & 14.39 & 8.92 \\ \mathrm{Na}^{+} & 18.11 & 27.32 & 3.80 \\ \mathrm{~K}^{+} & 0.72 & 0.65 & 0.85\end{array}$

Available nutrients, $\mathrm{ppm}{ }^{*}$

$\begin{array}{cccc}\mathrm{N} & 3.80 & 4.96 & 22.16 \\ \mathrm{P} & 6.59 & 6.42 & 12.27 \\ \mathrm{~K} & 42 & 24 & 89\end{array}$

*In saturation paste extract

**On dry weight basis 
Table 3The experiment included eighteen treatments with three replicates (three different soils $\times$ six levels of fertilizers) as following

\begin{tabular}{|c|c|c|c|}
\hline & $\mathbf{N}$ & $\mathbf{P}$ & $\mathbf{K}$ \\
\hline $\begin{array}{l}\text { Application of mineral } \\
\text { fertilization }\end{array}$ & $\begin{array}{l}\text { Ammonium sulfate }(20.6 \% \\
\text { N) }\end{array}$ & $\begin{array}{l}\text { Calcium superphosphate (15\% } \\
\left.P_{2} O_{5}\right)\end{array}$ & $\begin{array}{l}\text { Potassium sulfate } \\
\left(48 \% \mathrm{~K}_{2} \mathrm{O}\right)\end{array}$ \\
\hline $100 \%$ & $500 \mathrm{~kg} / \mathrm{fed}$ & $150 \mathrm{~kg} / \mathrm{fed}$ & $50 \mathrm{~kg} / \mathrm{fed}$ \\
\hline $50 \%$ & $250 \mathrm{~kg} / \mathrm{fed}$ & $75 \mathrm{~kg} / \mathrm{fed}$ & $25 \mathrm{~kg} / \mathrm{fed}$ \\
\hline $25 \%$ & $125 \mathrm{~kg} / \mathrm{fed}$ & $37.5 \mathrm{~kg} / \mathrm{fed}$ & $12.5 \mathrm{~kg} / \mathrm{fed}$ \\
\hline
\end{tabular}

Table 4 Effect of bio and mineral fertilization and their interactions on growth parameters (plant height, number of branches, herb fresh weight Kg/plant and herb dry weight g/plant) of roselle plants under clay, sandy loam and saline loamy sand soils during the two successive seasons 2007 and 2008

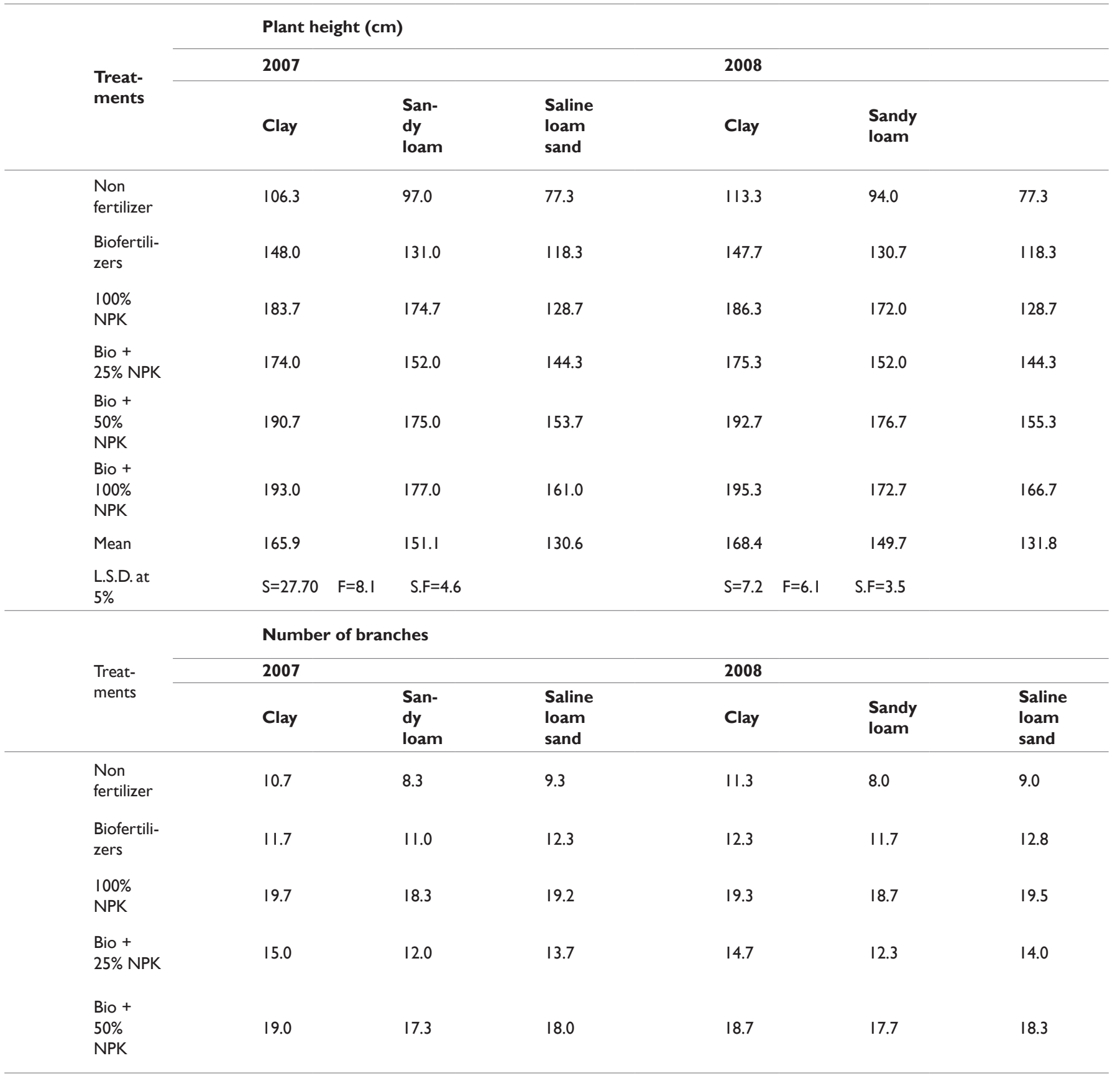


Table continued

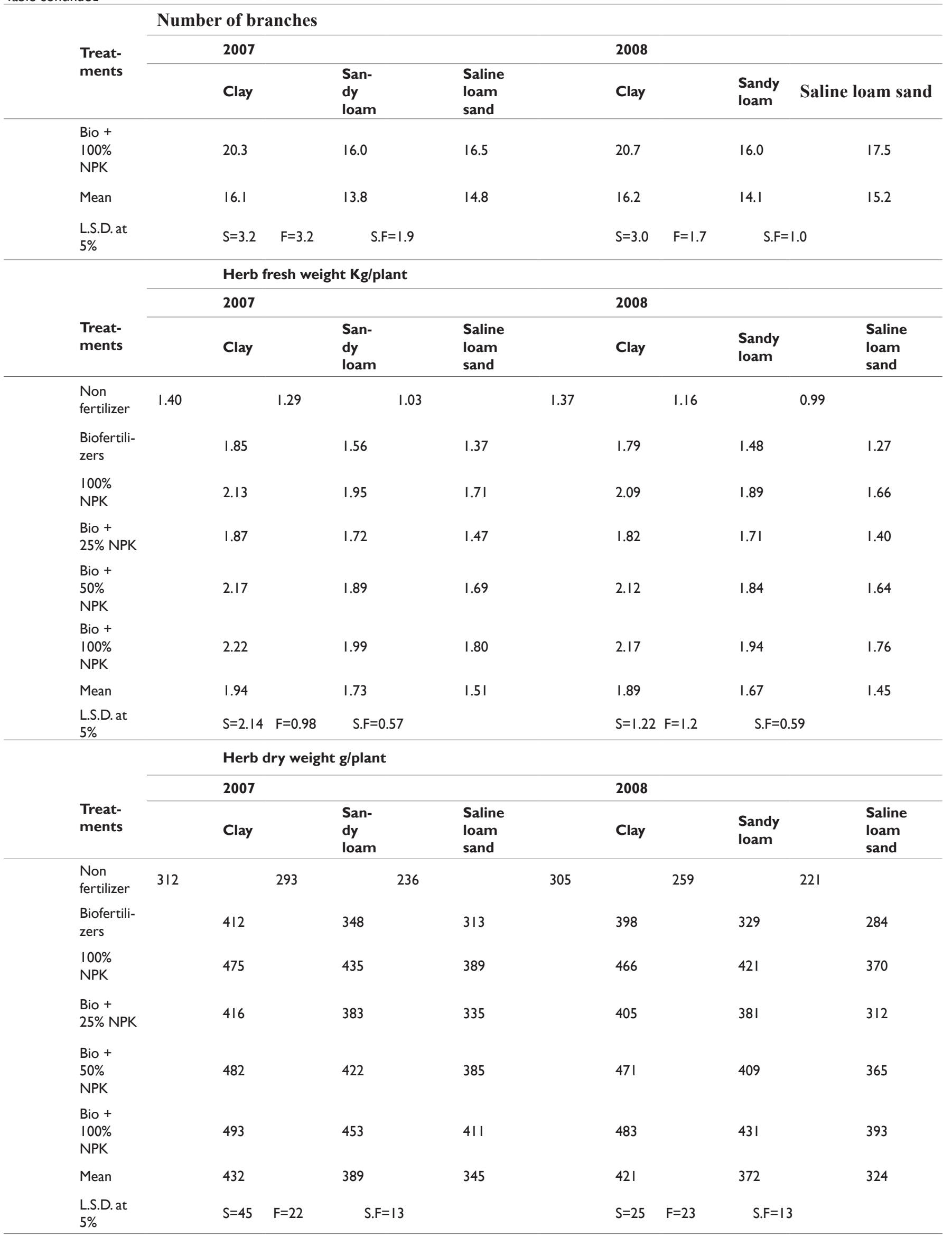


Table 5 Effect of bio and mineral fertilization and their interactions on yields and its components (sepals dry weight g/plant, sepals dry weight kg/fed, weight of seeds g/plant and weight of seeds $\mathrm{kg} / \mathrm{fed}$ ) of roselle plants under clay, sandy loam and saline loamy sand soils during the two successive seasons 2007 and 2008

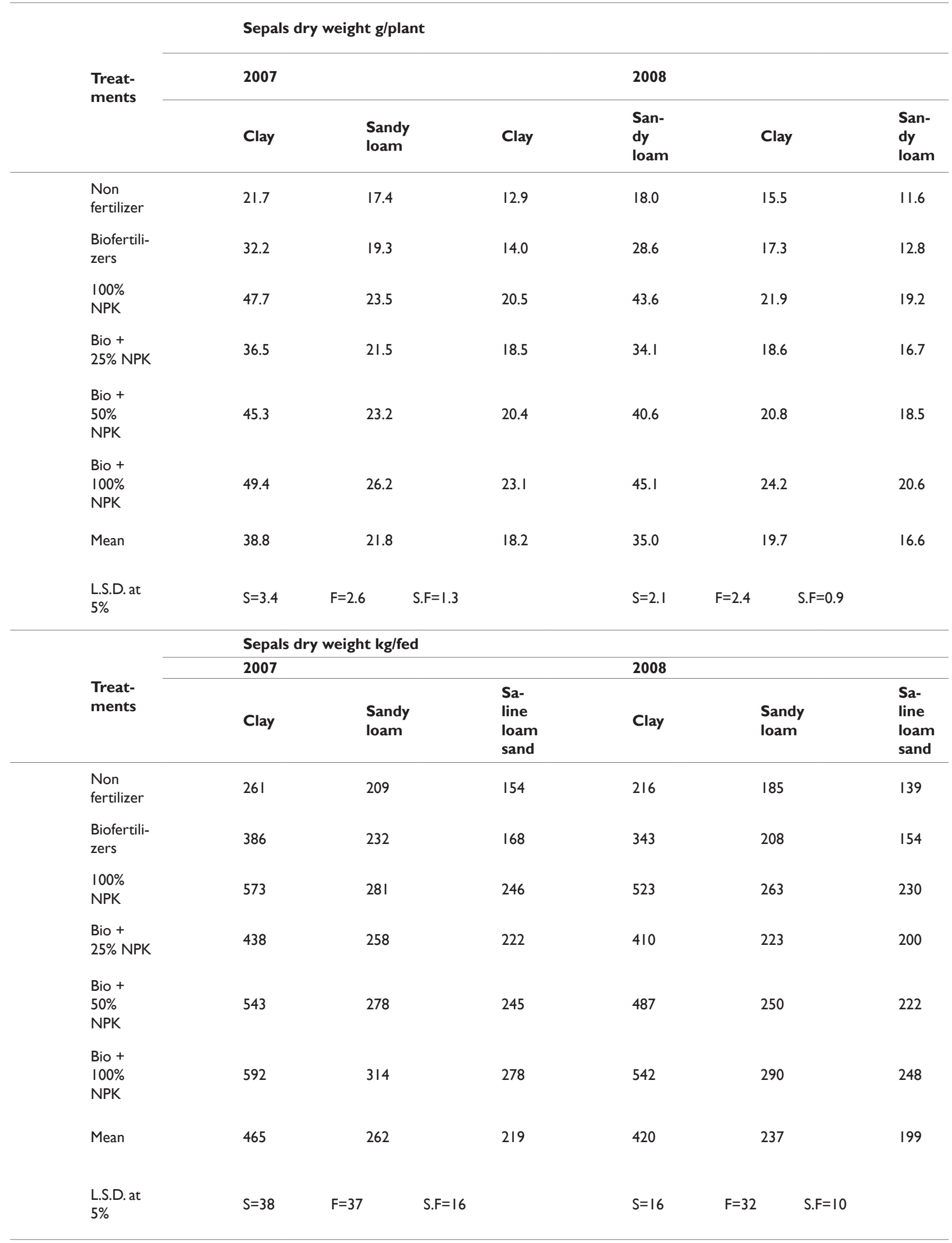




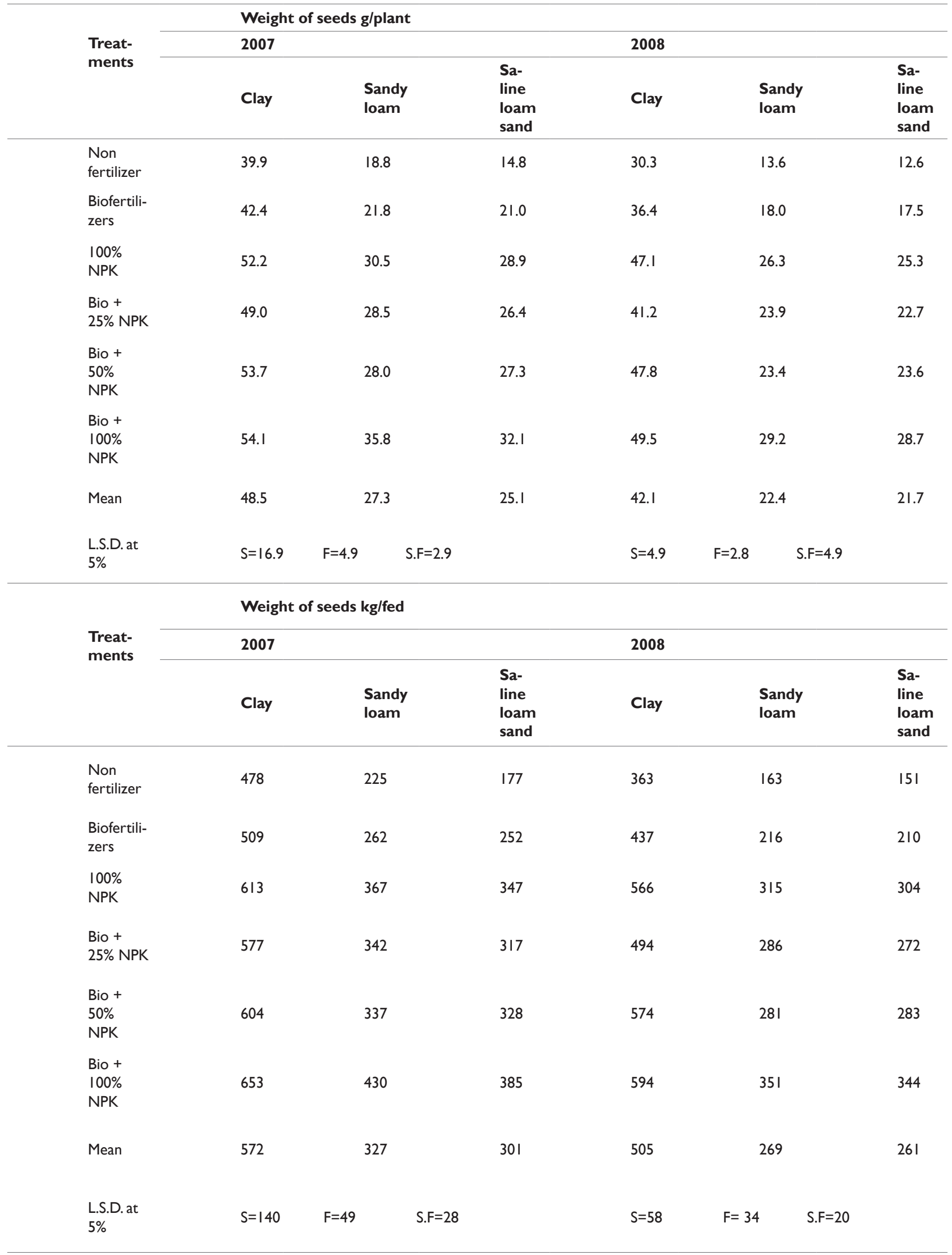




\section{Discussion}

Uses of bio-fertilizers containing beneficial microorganisms instead of synthetic chemicals are known to improve plant growth through the supply of plant nutrients and may help to sustain environmental health and soil productivity. In addition, the shortage and high cost of chemical fertilizers and their environmental pollution have been focused attention on uses of bio-fertilizers. The beneficial effect of inoculation of roselle seeds with bio-N \&P fertilizer combined with 25,50 and $100 \%$ of the recommended N\&P dose from the same nutrient as soil application, resulted in vigorous growth as well as highly productivity of plants with good quality. Moreover, the importance or the superiority for the applications of bio fertilizer was not only taken as a criterion for increasing the income for roselle crop or rationalize of costly mineral-N\&P fertilizers, but also for minimizing the possibly adverse fears of both human health and environmental risks resulted from uncontrolled use of mineral-N fertilizers. ${ }^{29}$ Thus supplying biological nitrogen fixing (BNF) for plant varieties need an excessive use mineral or chemical fertilizers, especially those of nitrogenous ones. Undoubtedly, the superiority of applied BNF bacteria is more attributed to the role of bacteria strains activity in decomposition of organic substances, which have ability to improve soil properties and, enhancing the released nutrients in mobile or available forms to uptake by plant roots. ${ }^{30}$ An increase in each of growth characters (plant height, etc...) was due to many factors such as (a) its ability to release plant promoting substances (mainly IAA, gibberellic acid and cytokinin like substances) which might be stimulated plant growth, ${ }^{31}$ (b) synthesis of some vitamins, e.g. B12,32 (c) increasing the water and mineral uptake from the soil. ${ }^{33}$ This could be ascribed to increase in root surface area, root hairs and root elongation as affected by Azotobacter, ${ }^{34}(\mathrm{~d})$ increasing the ability to convert $\mathrm{N}_{2}$ to $\mathrm{NH}_{4}$ and thus make it available to plant ${ }^{35}$ and (e) enhancing the production of biologically active fungistatical substances which may change the microflora in the rhizosphere and affect the balance between harmful and beneficial organisms. ${ }^{36}$ The increment in the studied growth characters might be attributed to the beneficial effect of bio fertilizers on the nutritional availability and its uptake. Numerous investigators explained the important role of bio fertilizers in reducing $\mathrm{pH}$ value by secreting organic acids such as acetic, propionic, fumaric and succinic acids, which brought about the dissolution of nutrients bound to organic materials and render them available for growing plants. ${ }^{37}$ The positive effect of inoculation had marked influence on the growth of plant, which was reflected to increase yield. This increase might be due to the effect of $\mathrm{N}$, which was produced by bacteria species, in addition of some growth regulators like IAA and $\mathrm{GA}_{3}$ which stimulated growth. Some bacteria called Plant Growth Promoting Rhizobacteria (PGPR), stimulate plant growth. ${ }^{38}$ The stimulatory effects of microorganisms may result from either direct or indirect action. Direct effects include production of phytohormones, ${ }^{39}$ enhancement of availability of some minerals, ${ }^{38}$ liberation of phosphates and micronutrients, nonsymbiotic nitrogen fixation and stimulation of disease-resistance mechanisms. ${ }^{40}$ Indirect effects arise from (PGPR) altering the root environment and ecology. ${ }^{41}$ For example, acting as biocontrol agents and reducing diseases, liberation of antibiotic substances that kill noxious bacteria. ${ }^{40}$ In this respect, ${ }^{35}$ suggested that addition of biofertilizer increase the ability to convert $\mathrm{N}_{2}$ to $\mathrm{NH}_{4}$, and thus make it available to plant. On the other hand, uses of bio-fertilizers combined with 50 and $100 \%$ of the recommended N\&P dose from the same nutrient as soil application, resulted in vigorous growth as well as highly productivity of plants with good quality. In many agricultural production systems, nitrogen
$(\mathrm{N})$ has been identified as the most deficient essential nutrient. Nutrient inputs into production systems have increased as a result of the need for high yielding crops to sustain the growing population around the world. The optimum dose of nitrogen is very important to obtain the high yield without luxury consumption of nutrients. Improving the nitrogen use efficiency is an economic and environmental request due to the continuous raising fertilizer prices and pollution of soil and water. ${ }^{42}$ The present price hike of fertilizers is one of the main constraints to increase the economic yield of crops. Thus efforts are needed to minimize its losses and to enhance its economic use. An increasing the measured growth characters (plant height etc...) was due to that this fertilizer resulting in more availability of nitrogen to be absorbed by the tested plants. The positive effect of mineral-N fertilization on growth characters of plants may be attributed to the encourage role of nitrogen in protoplasm formation , proteins, amino acids, nucleic acids, many enzymes and energy transfer materials. ${ }^{43}$ Nitrogen also accelerating both cell division and elongation due to its great action in stimulating nutritional status and the growth parameters. The improving effect of $\mathrm{N}$ as foliar application on yield and its components was mainly attributed to its positive action on enhancing growth parameters (Table 5). In this concern ${ }^{44}$ concluded that applying $\mathrm{N}$ as soil application to wheat plants encouraged growth reproductive organs as well as wheat yield components and this in turn increased grain yield, this may due also to increase in green area intercepting solar radiation. This intern increases the amount of metabolites synthesized by plants. ${ }^{45}$ So, the above mentioned results showed that it could be obtained the highest yield with saving about $50 \%$ of mineral nitrogen (through application of bio N\&P treatment) and avoiding its undesirable effects. Moreover, the increase of total carbohydrates concentrations in plants sprayed with $\mathrm{N}$ may be directly or indirectly due to that the certain enzymes may be activated the anabolic processes leading to the accumulation of these substances. Moreover the positive effect of phosphate dissolving bacteria on growth might be attributed to the effect of these bacteria to encourage plant to produce some growth promoting substances such as auxine , gibberellins and cytokinens ${ }^{46}$ which may improve plant growth and stimulate microbial development in the rhizosphere ${ }^{47}$ and their positive action on mineralization and solubilization potential for organic and inorganic phosphorus, respectively. ${ }^{48}$ It is well known that the beneficial effects of plant growth-promoting rhizobacteria are attributed to the production of diverse metabolites including siderophores, hydrocyanic acid (HCN), IAA and other associated activities such as good phosphate solubilization and competition in soil and root colonization. ${ }^{41}$ Moreover, it was found that the application of phosphate dissolving bacteria as a biofertilizer resulted in a reduction of soil $\mathrm{pH}$ which increased the solubility of some nutrients such as $\mathrm{P}$, $\mathrm{Fe}, \mathrm{Zn}, \mathrm{Mn}$ and $\mathrm{Cu}$ which in turn increased nutrient uptake by plants. ${ }^{49}$

Finally, from the present results, it could be concluded that the application of bio application of nitrogen and phosphorous greatly increased growth and yield as well as improved quality due to that, these element participate in the different metabolic processes which increased syntheses of carbohydrates and absorption of essential nutrient, so that the use of N\&P as bio and soil application could be used for producing plants with high sufficient cellular solutes enable them to overcome salinity of soils, and consequently producing greatest yield with high quality of rosella plants.

\section{Acknowledgements}

None. 


\section{Conflicts of interests}

Authors declare no conflict of interest exists.

\section{References}

1. Azer EA. Effect of soil type and salinity on roselle plant (Hibiscus sabdariffa, L.). M. Sc. Thesis Fac. of Agric Cairo Univ. 1992

2. Sajid A, Khan AR, Mairaj G, et al. Assessment of different crop nutrient management practices for yield improvement. Australian J of Crop Sciense. 2008;2(3):150-157.

3. Martínez JM, Galantini JA, Duval ME. Contribution of nitrogen mineralization indices, labile organic matter and soil properties in predicting nitrogen mineralization. J Soil Sci Plant Nutr. 2018;18:73-89.

4. Kannayan S. Biofertilizers for sustainable crop production, bio technology of biofertilizers. Narosa Publishing House, New Delhi, India. 2002;9-49.

5. Ehteshami SMR, Aghaalikhani M, Khavazi K, et al. Effect of phosphate solubilizing microorganisms on quantitative and qualitative characteristics of maize (Zea mays L.) under water deficit stress. Pakistan Journal of Biological Sciences. 2007;10(20):3585-3591.

6. Shaheen,AM, Rizk Fatma A, Omiama Sawan,M, et al. The integrated use of Bio-inoculants and chemical nitrogen fertilizer on growth, yield and nutritive value of two okra (Abelmoschus Esculentus, L.).cultivars. Australian Journal of Basic and Applied Sciences. 2007;1(3):307-312.

7. Segura LGC, Sialongo KMR. Bio-N fertilizer application on the growth and yield of sweet corn (Zea mays var.rogu sa). A special project presented to the faculty of crop science unit college of agriculture, xavier university in partial fulfillment of the requirement for the course Agri. 2005;124

8. Khalil MAI, Mohsen AAM, Abdel-Fattah MK. Effect of bio and mineral nitrogen fertilization on growth, yield and quality of lettuce plants under sandy soil conditions. Middle East Journal of Applied Sciences. 2016;6(2):411-417

9. Abdel-Nabi HMA, KD Kawther, EIEl-Gamily, et al. Impact of mineral, organic and bio fertilization on growth, yield and quality of cantaloupe. J Plant Production Mansoura Unv. 2016;(11):1777-1794.

10. Gawali, R. and Shila, R, P.K. Unni. (2018). Integrated nutrien management approach on wheat (Triticum aestivum L.) in Vertisols. Int J Curr Microbiol App Sci. 2018;7(4):3144-3153.

11. Singh DYV, Tyagi S. Effect of Biofertilizer, herbicide application and nitrogen management on growth, productivity of Wheat (Triticum aestivum L.). Int J Curr Microbiol App Sci. 2019;8(4):2712-2719.

12. Hammad KHA, HA Hussein. Effect of NPK and chicken manure on the growth productivity and som growth components of squash (Cucurbita pepo L.). ARPN J of Agric And Bio sci. 2016;11(6):230-235.

13. Ehiokhlien KERU, Samson AE, Henry AO, et al. Performance of watermelon (Citrullus lanatus L.) in response to organic and NPK fertilizers. J Agric Enviro. 2017;9:5-17.

14. Arab Z. Effect of nitrogen fertilizers forms on fruit yield and quality of squash plants (Cucurbita pepo L.). 2018.

15. Aranguren M, Castellón A, Aizpurua A. Topdressing nitrogen recommendation in wheat after applying organic manures: The use of field diagnostic tools. Nutr Cycl Agroecosyst. 2018;110:89-103.

16. Ahmad M, Ahmad I, Hilger TH, et al. Preliminary study on phosphate solubilizing Bacillus subtilis strain Q3 and Paenibacillus sp. strain Q6 for improving cotton growth under alkaline conditions. Peer $J$. 2018;6:e5122.
17. Siddiqui MH, Chandoa F, Abbasi M, et al. Effect of NPK, micronutrients and n-placement on the growth and yield of sunflower. Sarhad J Agric. $2009 ; 25:(1) 45-52$

18. Khan AA, Jilani G, Akhtar MS, et al. Phosphorus solubilizing bacteria: occurrence, mechanisms and their role in crop production. J Agric Bio Sci. 2009;1(1):48-58.

19. El-Ganaini SS. Effect of phosphorus and some micronutrients fertilizers on growth, yield and some chemical constituents of sunflower (Helianthus annuus L.) plants grown under reclaimed soil conditions. Fayoum J Agric Res Dev. 2009;23(2):94-107.

20. El-Nagdy GA, Nassar DM, El-Kady EA, et al. Response of flax plant (Linum usitatissimum L.) to treatments with mineral and biofertilizers from nitrogen and phosphorus. Journal of American Science. 2010;6(10):207-217.

21. Yosefi1 K, Galavi1 M, Ramrodi M, et al. Effect of bio-phosphate and chemical phosphorus fertilizer accompanied with micronutrient foliar application on growth, yield and yield components of maize (Single Cross 704). AJCS. 2011;5(2):175-180.

22. Ragab T. Magesium and phosphorien application improve the efficiency of growth and productivity of squash plants grown on sandy calcareous soil. J of Advanced Botany and zoology. 2016;(4):1-6.

23. Baliah TN, Priya AS. Effect of bioformulations of Phosphate Solubilizing Bacteria (PSB) on the Growth and Biochemical Characters of the Gossypium Hirsutum and Zea Mays. International Journal of Environment, Agriculture and Biotechnology (IJEAB). 2017;2(6):32293236.

24. Zheng BX, Ibrahim M, Zhang DP, et al. Identification and characterization of inorganic-phosphate-solubilizing bacteria from agricultural fields with a rapid isolation method. AMB Expr. 2018;8(47):2-12.

25. Li H, Ding X, Chen C, et al. Enrichment of phosphate solubilizing bacteria during late developmental stages of eggplant ( Solanum melongena L.). FEMS Microbiology Ecology. 2019;95(3)pii:fiz023.

26. Prakash J, Arora N. Phosphate-solubilizing Bacillus sp. enhances growth, phosphorus uptake and oil yield of Mentha arvensis L. 3 Biotech. 2019;9(126):1-9.

27. Allen ON. Experimentals in soil bacteriology. Burgess Publishing, Minneapolis, Minnesota, USA. 1971

28. Snedecor WC, Cochran WG. Statistical methods. 7th edn. The Iowa state Univ Press, Ames, Iowa USA. 1980.

29. Hellal FA, Mahfouz SA, Hassan FAS. Partial substitution of mineral nitrogen fertilizer by bio-fertilizer on (Anethum graveolens L.). plant Agric Biol JN Am. 2011;2(4):652-660.

30. Salib MM. The integrated effect of humic acid and micronutrients in combination with effective micro-organisms on wheat and peanut grown on sandy soils. Zagazig J Agric Res. 2002;29(6):2033-2050.

31. El-Merich C, DE-Zamarozy M, Arsene F, et al. Regulation of NIF gene expression and nitrogen metabolism in Azospirillium. Soil Biol \& Biochem. 1997;29(5\&6):847-852.

32. Okon Y, Labandera- Gonzalez CA. Agronomic application of Azospirillium. An evaluation of 20 yeara world wide field inoculation. Soil Bioch. 1984;26:1951-1601

33. Amara MT, Dahdoh MSA. Effect of inoculation with plant growth promoting rhizobacteria (PGPR) on yield and uptake of nutrients by wheat grown on sandy soil. Egypt J Soil Sci. 1997;4:467-484.

34. Sundaravelu S, Muthukrishinan T. Effect of seed treatment with Azospirillium and gibberellic acid on the growth and yield of radish. South India Hort. 1993;41(4):212-213. 
35. Ahmed AAH, Khir NF, Talaat NB. Physiological studies on reducing the accumulation of nitrate in jews mallow (Corchorus olitorius L.) and radish (Raphanus sativus L.). Bull Fac Agric Cairo Univ. 1997;48:2564.

36. Apte R, Shendi ST. Studies on Azotobacter chroococcum and their effect on crop yield. Zbl Bakt II. 1981;136:637-640.

37. Ibrahim AN, Abd El-Aziz IM. Solubilization of rock phosphate by streptomyces. Agric Talajton. 1977;26:424-434.

38. Kapulnik Y. Plant growth promoting rhizobacteria. In: Plant Roots, The Hidden Half. Marcel Dekker, New York, 1991;717-729.

39. Noel TC, Sheng,C. Yost CK, et al. Rhizobium leguminosarum as a plant growth promoting rhizobacterium: direct growth promotion of canola and lettuce. Can J Microbiol. 1996;42:279-283.

40. Lazarovits G, Nowak J. Rhizobacteria for improvement of plant growth and establishment. Hort Sci. 1997;32 (2):188-192.

41. Glick BR. The enhancement of plant growth by free-living bacteria. Can J Microbiol. 1995;47:109-117.

42. Addiscott TM, Whitmore AP, Powlson DS. Fertilizers and nitrate problem. Redwood Press LTD, Melksham, UK; 1991:170.

43. Zaki Nabila M, Hassanein MS, Gamal El-Din, et al. Growth and yield of some wheat cultivars irrigated with saline water in newly cultivated land as affected by biofertilization. $J$ of Appl Sci Res. 2007;3(10):1121-1126.

44. El-Bialy US, El-Shafie AI, Ahmed AI. Efficiency of soil and foliar application of potassium fertilizer on yield, yield components and some nutritional constituents of wheat grown on alluvial bahtim soil. Egypt J Appl Sci. 2001;16(1):297-313.

45. Oad FC, Buriro UA, Siddiqui MH. Yield and yield components of wheat under inorganic nitrogen levels and application untreated. Int J Agric Biol. 2004;6(6):1159-1161.

46. Sabik FA, Baza MSM, Monged NO. Effect of biofertilizer and micronutrients applied with different methods on faba bean. Egypt $J$ Agric Sci. 2001.

47. Abd El-Rasoul ShM, El-Banna AA, Abd El-Moniem MM, et al. Bio and organic fertilization for peanut plant grown on new reclaimed sandy soil. Egypt J Appl. Sci. 2002;17(7):127-142.

48. Khiari L, Parent LE. Phosphorus transformations in acid light-textured soils treated with dry swine manure. Can J Soil Sci. 2005;85:75-87.

49. Saber MSM, Kabesh MO. Utilization of biofertilizers in field crop production. II-A comparison study on the effect of biofertilization or sulpher application on yield and nutrients uptake by lentil plants. Egypt J Soil Sci. 1990;30(3):415-422. 